\title{
Tumor-induced osteomalacia: experience from three tertiary care centers in India
}

\author{
Rimesh Pal ${ }^{1}$, Sanjay Kumar Bhadada', Awesh Singhare ${ }^{2}$, Anil Bhansali ${ }^{1}$, Sadishkumar Kamalanathan ${ }^{3}$, \\ Manoj Chadha ${ }^{2}$, Phulrenu Chauhan ${ }^{2}$, Ashwani Sood ${ }^{4}$, Vandana Dhiman ${ }^{1}$, Dinesh Chandra Sharma ${ }^{5}$, \\ Uma Nahar Saikia ${ }^{6}$, Debajyoti Chatterjee ${ }^{6}$ and Vikas Agashe ${ }^{7}$ \\ 'Department of Endocrinology, Post Graduate Institute of Medical Education and Research, Chandigarh, India \\ 2Department of Endocrinology, P D Hinduja Hospital and Medical Research Centre, Mumbai, India \\ ${ }^{3}$ Department of Endocrinology, Jawaharlal Institute of Post Graduate Medical Education and Research, Pondicherry, India \\ ${ }^{4}$ Department of Nuclear Medicine, Post Graduate Institute of Medical Education and Research, Chandigarh, India \\ ${ }^{5}$ Division of Endocrinology, Rabindranath Tagore Medical College, Udaipur, India \\ ${ }^{6}$ Department of Histopathology, Post Graduate Institute of Medical Education and Research, Chandigarh, India \\ ${ }^{7}$ Department of Orthopaedics, P D Hinduja Hospital and Medical Research Centre, Mumbai, India
}

Correspondence should be addressed to S K Bhadada: bhadadask@rediffmail.com

\begin{abstract}
Tumor-induced osteomalacia (TIO) is a rare paraneoplastic syndrome characterized by recalcitrant hypophosphatemia. Reports from the Indian subcontinent are scarce, with most being single center experiences involving few patients. Herein, we conducted a retrospective analysis of 30 patients of TIO diagnosed at three tertiary care hospitals in India. Patients with persistent hypophosphatemia (despite correction of hypovitaminosis D), normocalcemia, elevated alkaline phosphatase, low TmP/GFR and elevated or 'inappropriately normal' FGF23 levels were labeled as having TIO. They were sequentially subjected to functional followed by anatomical imaging. Patients with a well-localized tumor underwent excision; others were put on phosphorous and calcitriol supplementation. The mean age at presentation was 39.6 years with female:male ratio of 3:2. Bone pain (83.3\%) and proximal myopathy (70\%) were the chief complaints; $40 \%$ of cases had fractures. The mean delay in diagnosis was 3.8 years. Tumors were clinically detectable in four patients (13.3\%). The mean serum phosphate was $0.50 \mathrm{mmol} / \mathrm{L}$ with a median serum FGF23 level of $518 \mathrm{RU} / \mathrm{mL}$. Somatostatin receptor-based scintigraphy was found to be superior to FDG-PET in tumor localization. Lower extremities were the most common site of the tumor (72\%). Tumor size was positively correlated with serum FGF23 levels. Twenty-two patients underwent tumor resection and 16 of them had phosphaturic mesenchymal tumors. Surgical excision led to cure in $72.7 \%$ of patients whereas disease persistence and disease recurrence were seen in $18.2 \%$ and $9.1 \%$ of cases, respectively. At the last follow-up, serum phosphate in the surgically treated group was significantly higher than in the medically managed group.
\end{abstract}

\author{
Key Words \\ - tumor-induced \\ osteomalacia \\ - FGF23 \\ - hypophosphatemia \\ - phosphaturic \\ mesenchymal tumor
}

\section{Introduction}

Tumor-induced osteomalacia (TIO), also known as oncogenic osteomalacia, is a rare paraneoplastic syndrome characterized by persistent hypophosphatemia. The basic pathophysiology of underlying hypophosphatemia is increased renal phosphate wasting consequent to raised levels of circulating phosphatonins. The best-characterized phosphatonin is fibroblast growth factor 23 (FGF23), a $32 \mathrm{kDa}$ polypeptide consisting of 251 amino acids (1). In addition, other phosphatonins like secreted frizzled protein-4, matrix extracellular phosphoglycoprotein

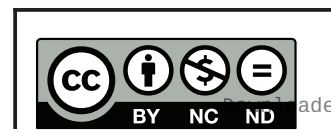

This work is licensed under a Creative Commons Attribution-NonCommercial-NoDerivatives 4.0 enternationad ticense ifica.com at 04/26/2023 11:49:04AM 
(MEPE), FGF 7 and certain non-collagenous matrix proteins called SIBLING have also been implicated $(2,3$, $4,5,6,7)$. In most cases, small, benign, mesenchymal soft tissue tumors are responsible for the increased FGF23 production $(8,9)$. Besides causing phosphaturia, FGF23 inhibits renal $1 \alpha$-hydroxylase, the enzyme that converts 25-hydroxy vitamin $\mathrm{D}$ to its active form, 1,25-dihydroxy vitamin D (10). Low levels of active vitamin $\mathrm{D}$ further impairs intestinal absorption of phosphate and deters mineralization of the osteoid matrix. Chronic hypophosphatemia leads to skeletal manifestations of osteomalacia in adults and rickets in children (11). Adults complain of bone pains, fatigue, proximal myopathy and fragility fractures (12). Untreated TIO leads to significant morbidity and can be debilitating (13). Fortunately, complete tumoral excision leads to rapid normalization of biochemical parameters and resolution of symptoms (14). Around 300 cases of TIO have been reported worldwide, however reports from the Indian subcontinent are limited $(2,15,16,17,18,19,20,21)$. Herein, we describe the clinical features, biochemical parameters, imaging modalities and the treatment outcome in 30 patients of TIO diagnosed at three tertiary care hospitals in India.

\section{Materials and methods}

A retrospective analysis of the medical records of TIO cases diagnosed at three tertiary care hospitals from January 2011 to December 2017 was conducted.

All patients (more than 18 years of age) who presented to us with symptoms suggestive of osteomalacia (namely bone pain, proximal muscle weakness and/or fragility fractures) underwent a detailed historical evaluation with special emphasis on duration of symptoms and similar family history. All patients who had a similar family history were excluded as they were more likely to be hereditary causes of hypophosphatemic osteomalacia rather than TIO. A thorough physical examination, concentrating on any 'lumps or bumps' present on the body, was performed in all patients.

Blood samples for biochemical investigations were collected after $8 \mathrm{~h}$ of overnight fasting. Serum calcium (reference range (RR) $2.15-2.55 \mathrm{mmol} / \mathrm{L}$ ), inorganic phosphate (RR 0.87-1.45 mmol/L), albumin (RR 4.93-6.96 $\mathrm{mol} / \mathrm{L})$, alkaline phosphatase (RR 40-129IU/L) and creatinine (RR 35.36-106.06 $\mu \mathrm{mol} / \mathrm{L}$ ) were measured by autoanalyzer (Roche Diagnostics, Modular $P$ 800). Calcium values were corrected for respective serum albumin levels. Serum iPTH (RR 1.6-6.9 pmol/L) and 25(OH)D (RR 27.1-107 nmol/L) were measured by electrochemiluminescence assay using commercially available kits (Elecsys 2010 system, Roche Diagnostic). Those having hypovitaminosis $\mathrm{D}$ at the time of presentation were parenterally supplemented with 6 lakhs IU of cholecalciferol and a biochemical panel was repeated after 4 weeks. Patients who remained symptomatic and continued to have hypophosphatemia even after correction of serum vitamin D levels were suspected of having hypophosphatemic osteomalacia. In them, subsequently, TmP/GFR was calculated with the help of the standard nomogram (22). Finally, those patients having refractory hypophosphatemia, normocalcemia, elevated ALP and low TmP/GFR underwent estimation of serum FGF23 levels, using a two-site enzyme-linked immunosorbent assay (Human FGF23 (C-Term) ELISA, Quidel Immutopics, RR 0-150RU/mL, the coefficient of variation $<10 \%)$. Patients with the above biochemical profile and elevated or 'inappropriately normal' FGF23 levels were labeled as having TIO. Written informed consent for publication of their clinical details and/or clinical images was obtained from all the patients. Ethical clearance for the study was obtained from the Institutional Ethical Committee, Post Graduate Institute of Medical Education and Research, Chandigarh, India.

Biochemical confirmation was followed by imaging studies in an attempt to localize a culprit tumor. Functional imaging was carried out in most cases using somatostatin receptor-based scintigraphy $\left({ }^{68} \mathrm{Ga}\right.$-DOTATATE/DOTANOC, ${ }^{99 m}$ Tc-HYNIC-TOC scintigraphy), although ${ }^{18} \mathrm{~F}-\mathrm{FDG}$ PET/CT scan was used in some of the patients. Anatomical tumor localization was done using contrast-enhanced computed tomography (CT) or magnetic-resonance imaging (MRI) depending upon the nature of the suspected lesion with CT being preferred for bony lesions and MRI being preferred for soft tissue lesions. A thorough skeletal survey was performed in all patients including radiographs of the skull, cervical, thoracic, lumbosacral spine (antero-posterior/lateral), bilateral shoulders with proximal humeri, both bones of forearm, hands, rib cage, pelvis, proximal femur and both bones of the leg.

Patients with a well-localized tumor underwent excision, and post-surgery serum phosphate level was monitored daily till it got normalized. Serum FGF23 level was repeated 2 months after tumor resection. Patients with no tumor localization or surgically inaccessible tumors were medically managed with oral phosphate and calcitriol supplementation. Phosphate was supplemented in the form of sodium phosphate granules at a starting dose of $20 \mathrm{mg} / \mathrm{kg} /$ day in four to five divided doses which

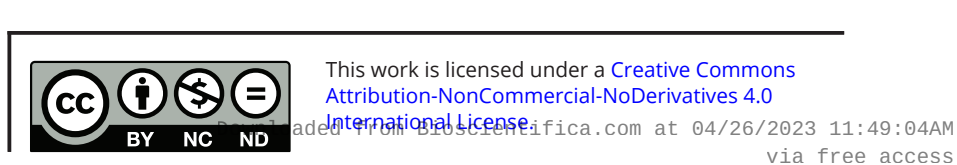


was gradually hiked up to a dose of $50 \mathrm{mg} / \mathrm{kg} /$ day in an attempt to achieve serum phosphate in the low normal range. Calcitriol was supplemented at a starting dose of $20 \mathrm{ng} / \mathrm{kg} /$ day in three divided doses and was titrated based on serum iPTH and urinary calcium levels. A baseline ultrasonography of the kidneys was done in all medically treated patients to rule out nephrolithiasis /nephrocalcinosis and was repeated half yearly. Surgically treated patients presenting with recurrence or persistence of symptoms underwent repeat imaging in an attempt to localize any residual or recurrent lesion. Subsequently, they either were reoperated or put on medical management. Serum phosphate levels at the last follow-up were compared between the surgically treated and the medically managed groups.

Statistical analysis was carried out using the Statistical Package for Social Sciences (SPSS) 23.0 software program (SPSS Inc.). Shapiro-Wilk test was used to check normality of data. Normally distributed variables were expressed as mean \pm S.D. Correlations between serum phosphorous, FGF23, tumor size and $\mathrm{SUV}_{\max }$ were calculated using Spearman correlation. Student's t-test (independent samples) was used to compare serum phosphate levels at initial presentation and the last follow-up as well as preand postoperative serum FGF23 levels.

\section{Results}

Over a period of 7 years from 2011 to 2017, a total of 30 cases of TIO were diagnosed at the three tertiary care hospitals of India. The demographic data and the biochemical investigations of all the 30 TIO patients have been summarized in Table 1 . The chief presenting complaints were bone pain (83.3\%), followed by proximal muscle weakness $(70 \%)$. Pathological fractures were seen in 12 patients (40\%); the most common site being the neck of femur, however none had vertebral fractures. The mean age of patients with and without fractures was comparable (40.0 vs 40.4 years). Physical examination could locate the culprit tumors in four (13.3\%) patients (Table 2). Three of them were visible to the naked eye (patient 8 (over the right leg just below the knee), patient 11 (over the back) and patient 17 (over the lateral aspect of the left leg)) (Fig. 1). Patient 9, a 40-year-old female, had a palpable firm, globular mass in the right gluteal region that was picked up on dedicated physical examination.

Functional localization of the lesion was undertaken in all but one patient (patient 17, who had a visible lump over the lateral aspect of the left leg, in whom only a contrast-enhanced computerized tomography was performed) (Table 3). Whole-body somatostatin receptor (SSTR)-based scintigraphy was performed in most patients, namely, ${ }^{68} \mathrm{Ga}$-DOTATATE/DOTANOC scintigraphy in 20 patients and ${ }^{99 \mathrm{~m}} \mathrm{Tc}-\mathrm{HYNIC}-\mathrm{TOC}$ scan in two patients (Fig. 2). ${ }^{18} \mathrm{~F}$-FDG-PET was performed in six patients while both SSTR-based scintigraphy and FDG-PET was done in one patient (and both had failed to localize any tracer-avid lesion). Subsequently, a definite anatomical lesion could be localized in 25 patients (83.3\%). The most common site of tumor localization was the lower extremity (72\%) followed by the nasal cavity and paranasal sinuses (16\%). One patient had a subcutaneous lesion over the back, while in two patients the lesion was localized in the mandible (patients 2 and 28). Most of the lesions were soft tissue tumors $(60 \%)$, while the rest $(40 \%)$ were seen to arise from bones. There was a statistically significant positive correlation between tumor size and FGF23 levels, while there was no significant correlation between $\mathrm{SUV}_{\max }$ (maximum standardized uptake volume obtained from SSTR-based scintigraphy) and serum FGF23 levels.

Out of the 25 patients in whom a definite tumor could be localized, 22 of them subsequently underwent surgery (patients 1 to 22). The most common histopathology was that of a phosphaturic mesenchymal tumor (16 patients, 72.7\%) (Fig. 3) followed by hemangiopericytoma (3 patients, 13.6\%). Two patients had giant cell tumors (patients 3 and 14), while one had an arteriovenous hemangioma of the left nasal cavity (patient 4). Postoperatively, serum phosphorous normalized in 18 patients, two of them (9.1\%) had a local recurrence and required reoperation (patients 12 and 16). Serum phosphorous did not normalize in four patients (18.2\%)

Table 1 Summary of the demographic data and biochemical investigations of all the $30 \mathrm{TIO}$ patients.

\begin{tabular}{l}
\hline Parameter \\
\hline Mean age (range) \\
Female:Male \\
Mean delay in diagnosis \\
(range) \\
Mean serum phosphate \\
(range) \\
Mean TmP GFR (range) \\
Mean corrected serum \\
calcium \\
Median serum ALP (IQR) \\
Median serum iPTH (IQR) \\
Median serum 25(OH)D \\
(IQR) \\
Median serum FGF23 \\
(IQR)
\end{tabular}




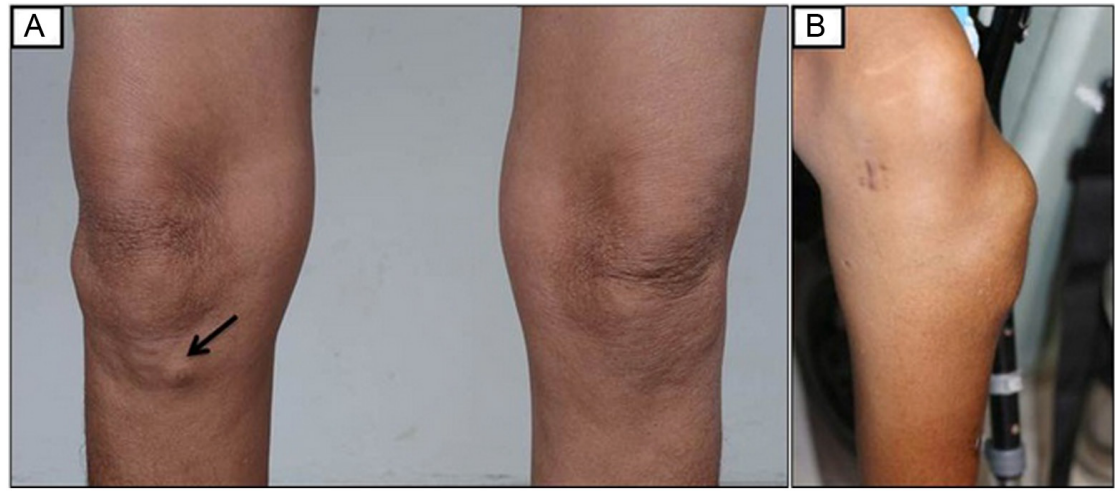

\section{Figure 1}

Clinical photographs of patient 8 showing a small lump just below the medial aspect of the right knee (A, marked in black arrow) and patient 17 showing a large lobulated lump over the lateral aspect of the upper left leg (B).

with persistent disease (patients 2, 3, 14 and 19). They were subsequently put on oral phosphorous and calcitriol supplementation. Postoperative serum FGF23 levels were available in 17 patients and there was a statistically significant decline in FGF23 levels compared to baseline $(P=0.002)$. Patient 2 had persistent disease and postoperative FGF23 levels showed a rise (307 vs $201 \mathrm{RU} / \mathrm{mL}$ at baseline). In another patient with persistent disease (patient 14), FGF23 remained high (1216 vs 3990 RU/mL at baseline).

Surgery could not be done in eight patients; five of them did not have tumor localization (patients 23, 25, 26, 28,29 ), one had a surgically inaccessible tumor (patient 27 ) and two patients were not willing for surgery (patients $24,30)$. They were put on medical management. Baseline mean serum phosphate in the medically and surgically managed groups was almost similar $(0.45 \mathrm{vs} 0.55 \mathrm{mmol} / \mathrm{L}$,
$P=0.217)$. At their last follow-up, the mean serum phosphorous in the surgically treated group was higher than the medically treated group $(1.00 \mathrm{vs} 0.80 \mathrm{mmol} / \mathrm{L}$, $P=0.006)$.

\section{Discussion}

We have herein presented a retrospective series of 30 cases of TIO diagnosed at three tertiary care institute of the country over a period of 7 years. Our patients had a relatively younger age at presentation. Bone pain and proximal myopathy were the principal presenting complaints; fractures were seen in only $40 \%$ of the patients. The detailed physical examination was rewarding in four patients for detecting the primary lesion. SSTRbased scintigraphy proved superior to conventional

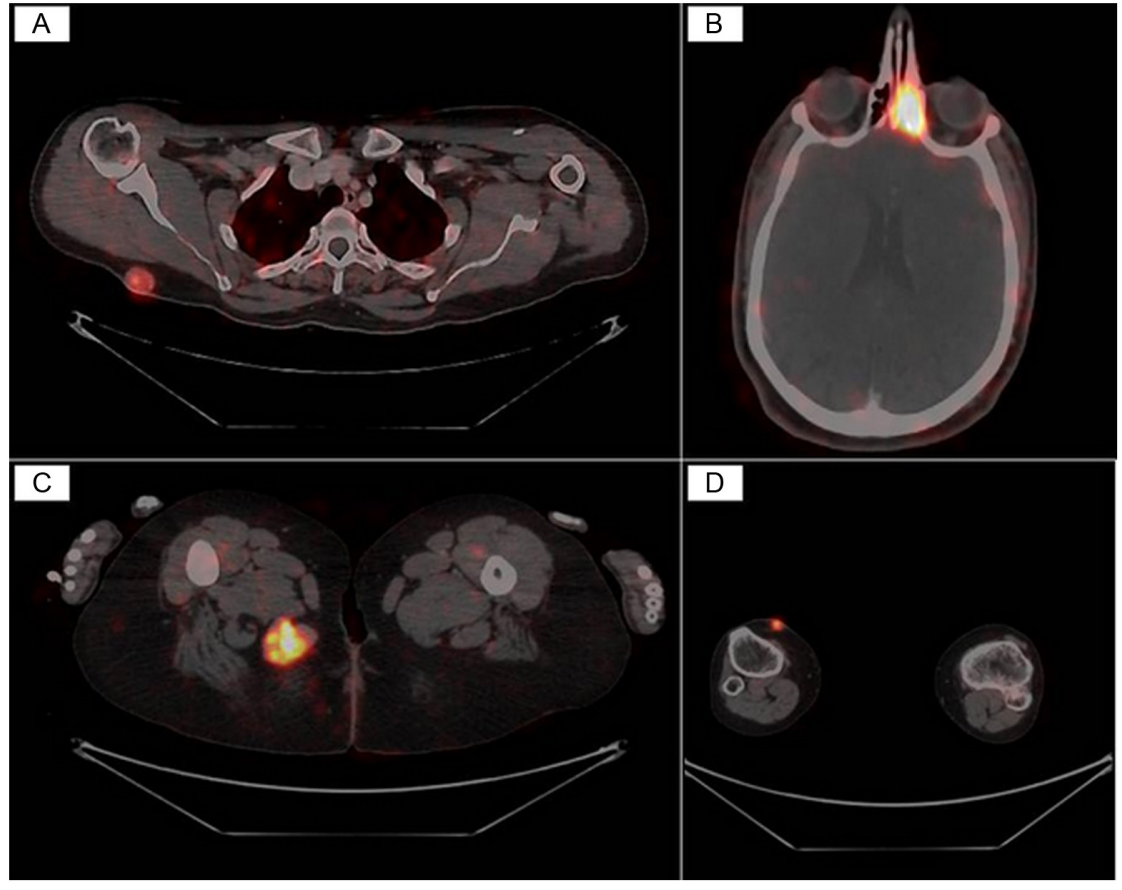

\section{Figure 2}

Fused ${ }^{68} \mathrm{Ga}$-DOTATATE PET/CT images showing focal tracer-avid lesions over the right back ( $A$, patient 11), left nasal cavity (B, patient 10), right gluteal region ( $C$, patient 9 ) and medial aspect of the leg just below the right knee (D, patient 8). https://ec.bioscientifica.com https://doi.org/10.1530/EC-18-0552 (c) 2019 The authors Published by Bioscientifica Ltd
This work is licensed under a Creative Commons Attribution-NonCommercial-NoDerivatives 4.0 denternationab bicense.ifica com at 04/26/2023 11:49:04AM 
Table 2 Demographic data and biochemical investigations of individual TIO patients $(n=30)$.

\begin{tabular}{|c|c|c|c|c|}
\hline Patient & Age/sex & $\begin{array}{c}\text { Phosphate } \\
\text { (mmol/L) }\end{array}$ & $\begin{array}{c}\text { Corrected } \\
\text { calcium } \\
(\mathrm{mmol} / \mathrm{L})\end{array}$ & $\begin{array}{l}\text { ALP } \\
(I U / L)\end{array}$ \\
\hline 1 & $55 / \mathrm{M}$ & 0.55 & 2.28 & 395 \\
\hline 2 & 28/M & 0.42 & 2.15 & 314 \\
\hline 3 & $26 / F$ & 0.23 & 2.05 & 343 \\
\hline 4 & $52 / F$ & 0.58 & 2.30 & 351 \\
\hline 5 & $34 / F$ & 0.65 & 2.28 & 240 \\
\hline 6 & $51 / \mathrm{M}$ & 0.52 & 2.50 & 178 \\
\hline 7 & $36 / F$ & 0.48 & 2.23 & 324 \\
\hline 8 & $44 / F$ & 0.48 & 2.30 & 476 \\
\hline 9 & $40 / F$ & 0.42 & 2.18 & 149 \\
\hline 10 & $58 / \mathrm{M}$ & 0.39 & 2.18 & 160 \\
\hline 11 & $53 / F$ & 0.23 & 2.35 & 180 \\
\hline 12 & $56 / F$ & 0.78 & 2.30 & 490 \\
\hline 13 & $41 / F$ & 0.45 & 2.03 & 212 \\
\hline 14 & $30 / \mathrm{M}$ & 0.71 & 2.18 & 173 \\
\hline 15 & 49/M & 0.55 & 2.20 & 141 \\
\hline 16 & $36 / F$ & 0.65 & 2.08 & 467 \\
\hline 17 & $43 / F$ & 0.29 & 2.35 & 189 \\
\hline 18 & $37 / M$ & 0.39 & 2.23 & 160 \\
\hline 19 & $67 / M$ & 0.45 & 2.35 & 433 \\
\hline 20 & $29 / F$ & 0.42 & 2.03 & 528 \\
\hline 21 & 42/M & 0.55 & 2.20 & 475 \\
\hline 22 & 25/M & 0.42 & 2.23 & 488 \\
\hline 23 & $38 / F$ & 0.45 & 2.50 & 220 \\
\hline 24 & 28/M & 0.58 & 2.35 & 324 \\
\hline 25 & $52 / F$ & 0.48 & 2.13 & 340 \\
\hline 26 & $28 / F$ & 0.74 & 2.33 & 139 \\
\hline 27 & 19/M & 0.71 & 2.30 & 212 \\
\hline 28 & $31 / F$ & 0.58 & 2.25 & 188 \\
\hline 29 & $35 / F$ & 0.48 & 2.28 & 160 \\
\hline 30 & $26 / F$ & 0.39 & 2.30 & 178 \\
\hline
\end{tabular}

FDG-PET in localizing the culprit tumors. Soft tissue tumors were more commonly encountered than bony tumors with thighs being the predominant site. The most common histological tumor subtype was phosphaturic mesenchymal tumor-mixed connective tissue type. Surgical excision led to cure in $72.7 \%$ of patients; disease persistence and disease recurrence were seen in $18.2 \%$ and 9.1\% of cases, respectively.

The mean age of our patients at the time of initial presentation was 39.6 years which is about half a decade earlier than what has been reported in world literature $(23,24,25)$. It is however in congruence with an earlier report from India (15), possibly implying that TIO tends to present somewhat earlier in our population. There was a female:male ratio of 3:2. Usually, TIO shows no gender predilection and tends to affect males and females equally $(24,26,27)$, hence, the female dominance of our series could merely reflect referral bias. However, occasional case series depicting a female preponderance has been reported in the past $(28,29)$. Most of our patients complained of bone pain

$\begin{array}{r}\hline \\ \hline \text { iPTH }(\mathrm{pmol} / \mathrm{L}) \\ \hline 6.04 \\ 7.48 \\ 28.95 \\ 5.63 \\ 4.52 \\ 6.42 \\ 3.17 \\ 7.35 \\ 4.45 \\ 10.19 \\ 8.29 \\ 4.73 \\ 31.60 \\ 6.37 \\ 13.68 \\ 6.51 \\ 11.88 \\ 10.53 \\ 5.65 \\ 6.03 \\ 5.31 \\ 2.00 \\ 5.40 \\ 9.65 \\ 8.48 \\ 4.44 \\ 18.02 \\ 7.01 \\ 9.41 \\ 13.51 \\ \hline\end{array}$

\begin{tabular}{|c|c|}
\hline $\begin{array}{r}\mathbf{2 5}(\mathrm{OH}) \mathbf{D} \\
(\mathrm{nmol} / \mathrm{L})\end{array}$ & $\begin{array}{l}\text { TmP GFR } \\
(\mathrm{mmol} / \mathrm{L})\end{array}$ \\
\hline 59.9 & 0.07 \\
\hline 174 & 0.19 \\
\hline 64.9 & 0.19 \\
\hline 27.2 & 0.19 \\
\hline 174 & 0.17 \\
\hline 135 & 0.25 \\
\hline 74.9 & 0.23 \\
\hline 56.9 & 0.42 \\
\hline 38.9 & 0.34 \\
\hline 81.9 & 0.18 \\
\hline 113 & 0.20 \\
\hline 39.9 & 0.46 \\
\hline 160 & 0.52 \\
\hline 115 & 0.65 \\
\hline 187 & 0.29 \\
\hline 84.9 & 0.39 \\
\hline 152 & 0.45 \\
\hline 123 & 0.55 \\
\hline 74.4 & 0.74 \\
\hline 67.1 & 0.40 \\
\hline 53.2 & 0.50 \\
\hline 48.9 & 0.40 \\
\hline 75.9 & 0.29 \\
\hline 44.4 & 0.53 \\
\hline 102 & 0.11 \\
\hline 127 & 0.61 \\
\hline 48.4 & 0.36 \\
\hline 53.9 & 0.46 \\
\hline 42.7 & 0.36 \\
\hline 174 & 0.36 \\
\hline
\end{tabular}

\begin{tabular}{|c|c|}
\hline $\begin{array}{c}\text { FGF23 (RU/ } \\
\mathrm{mL})\end{array}$ & $\begin{array}{l}\text { Phosphate at } \\
\text { last follow-up } \\
\text { (mmol/L) }\end{array}$ \\
\hline 288 & 1.03 \\
\hline 201 & 0.68 \\
\hline 918 & 0.71 \\
\hline 814 & 1.10 \\
\hline 148 & 1.36 \\
\hline 264 & 1.20 \\
\hline 1239 & 1.20 \\
\hline 349 & 1.23 \\
\hline 523 & 1.55 \\
\hline 513 & 1.49 \\
\hline 1936 & 1.13 \\
\hline 550 & 0.65 \\
\hline 1771 & 1.00 \\
\hline 3990 & 0.32 \\
\hline 2581 & 1.13 \\
\hline 2407 & 0.97 \\
\hline 4298 & 0.90 \\
\hline 6435 & 1.03 \\
\hline 244 & 0.65 \\
\hline 102 & 0.87 \\
\hline 257 & 1.03 \\
\hline 2620 & 0.90 \\
\hline 1110 & 0.78 \\
\hline 193 & 0.71 \\
\hline 258 & 0.78 \\
\hline 669 & 0.87 \\
\hline 341 & 0.74 \\
\hline 451 & 0.84 \\
\hline 197 & 0.94 \\
\hline 1628 & 0.81 \\
\hline
\end{tabular}

and proximal muscle weakness. However, only $40 \%$ of our patients had radiologically proven pathological fractures. This appears fairly low when compared to world literature that has reported fracture rates as high as $84-100 \%(23,24)$. The mean delay in presentation was 3.8 years, which is very similar to earlier reports $(23,30)$. Thirteen percent of the tumors were clinically identifiable as palpable or visible lumps, highlighting the importance of a thorough head-to-toe examination.

Biochemical investigations revealed hypophosphatemia and normocalcemia in all patients. Hypophosphatemia was severe in $60 \%$ of the patients having serum phosphate levels below $0.50 \mathrm{nmol} / \mathrm{L}$. Only $43.3 \%$ of the cases were vitamin D deficient or insufficient, as opposed to $70-100 \%$ of the general population in the Indian subcontinent (31). This is because most of our patients had been supplemented with vitamin $\mathrm{D}$ as an empirical treatment at primary care hospitals. The calculated TmP/GFR was low (compared to age- and sex-specific reference range) in all the patients, implying renal phosphate wasting. Serum FGF23 levels were elevated above the upper limit of the

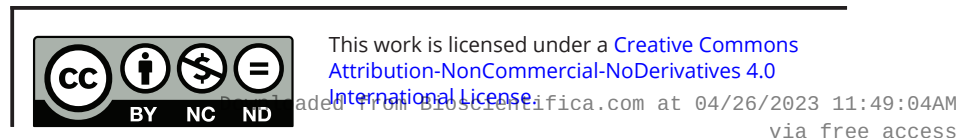




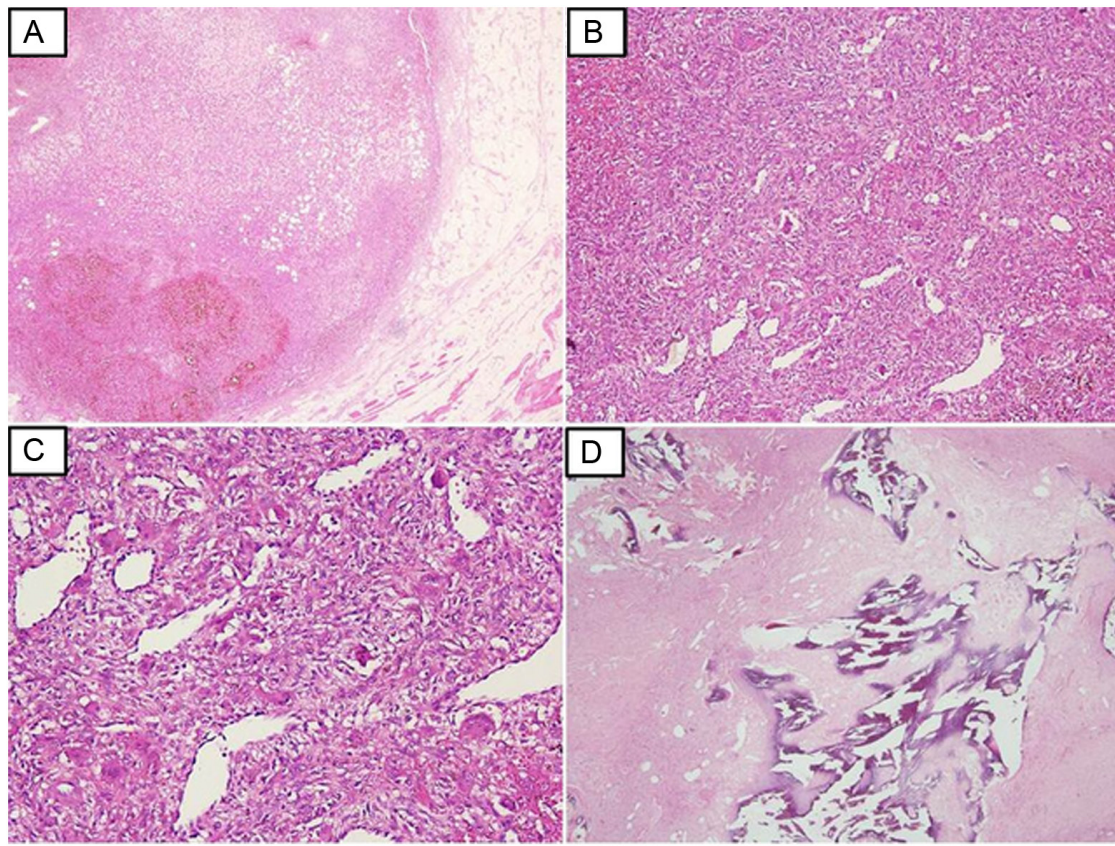

\section{Figure 3}

Photomicrograph of a phosphaturic mesenchymal tumor-mixed connective tissue type. (A) Photomicrograph showing a relatively wellcircumscribed and focally tissue permeating mass (hematoxylin and eosin; 20x). (B and C) Myoid spindle cell component along with hemangiopericytomatous blood vessels and scattered osteoclastic giant cells and siderophages (hematoxylin and eosin) (100x; 4b) (200x; 4c). (D) Other areas showing areas of grungy calcification along with the spindle cell component (hematoxylin and eosin; 40x).

assay range in all but two patients (patients 5 and 20). These two patients had serum FGF23 levels of 102 and $147 \mathrm{RU} / \mathrm{mL}$ with a corresponding serum phosphate of 0.42 and $0.65 \mathrm{nmol} / \mathrm{L}$, respectively, implying 'inappropriately normal' FGF23 for the degree of hypophosphatemia (30, 32). Moreover, estimation of FGF23 in our patients was done with C-terminal assay, the sensitivity of which does not reach $100 \%(33,34)$. Other phosphatonins could also be implicated in causing phosphaturia in these two patients $(4,5,6,7,35)$. We could not find any statistically significant correlation between serum phosphate and FGF23 levels $\left(r_{\mathrm{s}}=-0.22, P=0.24\right)$, probably because serum phosphate correlates with FGF23 measured by the intact assay rather than by the C-terminal assay (36).

Functional imaging (SSTR-based scintigraphy or FDG-PET) could localize a tracer-avid lesion in 28 out of 29 patients. However subsequent attempt at anatomical localization could pinpoint a culprit lesion in only 25 patients. The concordance rate between SSTR-based scintigraphy and anatomical imaging (defined as the ability of both the imaging modalities to localize a common lesion) was $100 \%$, while concordance between FDG-PET and anatomical imaging was only 50\%. The superiority of SSTR-based scintigraphy over FDG-PET in localizing culprit lesions in TIO is well documented in world literature $(37,38,39)$. Most of the localized lesions were of soft tissue origin (60\%). Forty percent of the tumors were seen to arise from bones, similar to what has been reported in most case series $(24,28)$. Although recent literature supports no clear anatomical predilection for the tumors (11), we found a striking lower limb predominance (72\%); thighs being the most common site. Two of our patients had multifocal benign tumors (patients 19 and 21), something that has rarely been reported $(16,21,40,41)$. One of them (patient 21), a 42-year-old male (16), had an FDG-avid nodule in the right leg (measuring $0.9 \times 0.6 \times 1.0 \mathrm{~cm}$ ) and a synchronous non-FDG-avid nodule in the left thigh that was picked up on MRI (measuring $0.8 \times 0.7 \mathrm{~cm}$ ). Excision of the FDG-avid nodule did not lead to the resolution of hypophosphatemia. However, when the non-FDG-avid lesion was removed, hypophosphatemia settled, and serum FGF23 came down to $22 \mathrm{RU} / \mathrm{mL}$.

Data on tumor size (as noted on CT/MRI) was available in 17 patients. Tumor size and serum phosphate were negatively correlated, though not statistically significant $\left(r_{\mathrm{s}}=-0.13, \quad P=0.61\right) ;$ on the contrary, there was a statistically significant positive correlation between tumor size and serum FGF23 levels $\left(r_{\mathrm{s}}=0.57, P=0.016\right)$, highlighting the fact that tumor size probably dictates the FGF23 levels. Data on maximum standardized uptake volume $\left(\mathrm{SUV}_{\max }\right)$ from ${ }^{68} \mathrm{Ga}$-labeled peptide scintigraphy was available in 15 patients. No statistically significant correlation between $\mathrm{SUV}_{\text {max }}$ and serum FGF23 levels $\left(r_{\mathrm{s}}=-0.17\right.$, $P=0.51)$ was found. Since $S U V_{\max }$ is a surrogate marker of SSTR expression (42), it may be inferred that signal transduction via somatostatin receptors is possibly not involved in the regulation of FGF23 secretion by the tumor tissue. As firm evidence to our hypothesis is the

This work is licensed under a Creative Commons Attribution-NonCommercial-NoDerivatives 4.0 Internationab kicense.ifica com at 04/26/2023 11:49:04AM 
Table 3 Various functional and anatomical imaging modalities used for tumor localization and histopathology of the tumors that were excised.

\begin{tabular}{|c|c|c|c|c|c|c|}
\hline Patient & $\begin{array}{l}\text { Functional imaging } \\
\text { used }\end{array}$ & $\begin{array}{l}\text { Site localized on } \\
\text { functional imaging }\end{array}$ & $\begin{array}{l}\text { Anatomical } \\
\text { imaging used }\end{array}$ & $\begin{array}{l}\text { Site localized on } \\
\text { anatomical } \\
\text { imaging }\end{array}$ & $\begin{array}{l}\text { Tissue of } \\
\text { origin }\end{array}$ & Histopathology \\
\hline 1 & ${ }^{68} \mathrm{Ga}$-DOTATATE & Right thigh & CEMRI & Concordant & Soft tissue & РMTMCT \\
\hline 2 & ${ }^{68} \mathrm{Ga}$-DOTATATE & Mandible & CECT & Concordant & Bone & HPT \\
\hline 3 & ${ }^{68} \mathrm{Ga}$-DOTATATE & Head of left fibula & CECT & Concordant & Bone & GCT \\
\hline 4 & ${ }^{68} \mathrm{Ga}-\mathrm{DOTATATE}$ & Right nasal cavity & CECT & Concordant & Soft tissue & AV hemangioma \\
\hline 5 & ${ }^{68} \mathrm{Ga}$-DOTATATE & Right thigh & CEMRI & Concordant & Soft tissue & PMTMCT \\
\hline 6 & ${ }^{68} \mathrm{Ga}-\mathrm{DOTATATE}$ & Shaft of right femur & CECT & Concordant & Bone & РMTMCT \\
\hline 7 & ${ }^{68} \mathrm{Ga}$-DOTATATE & Right maxillary sinus & CECT & Concordant & Soft tissue & РMTMCT \\
\hline 8 & ${ }^{68} \mathrm{Ga}$-DOTATATE & Right leg & CECT & Concordant & Soft tissue & РMTMCT \\
\hline 9 & ${ }^{68} \mathrm{Ga}-\mathrm{DOTATATE}$ & Right gluteal region & CEMRI & Concordant & Soft tissue & РMTMCT \\
\hline 10 & ${ }^{68} \mathrm{Ga}-\mathrm{DOTATATE}$ & Left nasal cavity & CECT & Concordant & Soft tissue & HPT-sinonasal type \\
\hline 11 & ${ }^{68} \mathrm{Ga}-\mathrm{DOTATATE}$ & Right back & CECT & Concordant & Soft tissue & РMTMCT \\
\hline 12 & ${ }^{68} \mathrm{Ga}-\mathrm{DOTATATE}$ & Right pelvic blade & CEMRI & Concordant & Bone & PMTMCT \\
\hline 13 & ${ }^{68} \mathrm{Ga}-\mathrm{DOTANOC}$ & Right thigh & CECT & Concordant & Soft tissue & РMTMCT \\
\hline 14 & FDG-PET & Left thigh & CECT & Concordant & Soft tissue & GCT \\
\hline 15 & ${ }^{68} \mathrm{Ga}-\mathrm{DOTANOC}$ & Right acetabulum & CEMRI & Concordant & Bone & РMTMCT \\
\hline 16 & FDG-PET & Left nasal cavity & CECT & Concordant & Soft tissue & HPT-lipomatous type \\
\hline 17 & NOT DONE & NA & CECT & $\begin{array}{l}\text { Left proximal } \\
\text { fibula }\end{array}$ & Bone & PMTMCT \\
\hline 18 & ${ }^{68} \mathrm{Ga}-\mathrm{DOTANOC}$ & Right heel & CEMRI & Concordant & Soft tissue & РMTMCT \\
\hline 19 & 99mTc-HYNIC-TOC & $\begin{array}{l}\text { Right medial femoral } \\
\text { condyle and S2 } \\
\text { vertebral body }\end{array}$ & CECT & Concordant & Bone & $\begin{array}{l}\text { PMT - osteoblastoma-like } \\
\text { variant }\end{array}$ \\
\hline 20 & 99mTC-HYNIC-TOC & Left thigh & CEMRI & Concordant & Soft tissue & РMTMCT \\
\hline 21 & FDG-PET & Right thigh & $\begin{array}{l}\text { CECT and } \\
\text { CEMRI }\end{array}$ & Left thigh & Soft tissue & РMTMCT \\
\hline 22 & FDG-PET & $\begin{array}{l}\text { Right proximal fibular } \\
\text { shaft }\end{array}$ & CECT & Concordant & Bone & РMTMCT \\
\hline 23 & FDG-PET & Left ala of sacrum & CEMRI & Not localized & NA & NA \\
\hline 24 & ${ }^{68} \mathrm{Ga}-\mathrm{DOTATATE}$ & Head of left femur & CEMRI & Concordant & Bone & NA \\
\hline 25 & ${ }^{68} \mathrm{Ga}$-DOTATATE & Right patella & CECT & Not localized & NA & NA \\
\hline 26 & $\begin{array}{l}{ }^{68} \mathrm{Ga}-\mathrm{DOT} A T A T E \\
\text { FDG-PET }\end{array}$ & Not localized & NOT DONE & NA & NA & NA \\
\hline 27 & ${ }^{68} \mathrm{Ga}$-DOTATATE & $\begin{array}{l}\text { Right obturator } \\
\text { muscle }\end{array}$ & CEMRI & Concordant & Soft tissue & NA \\
\hline 28 & ${ }^{68} \mathrm{Ga}-\mathrm{DOTATATE}$ & Mandible & CECT & Not localized & NA & NA \\
\hline 29 & FDG-PET & C4 vertebra & CECT & Not localized & NA & NA \\
\hline 30 & ${ }^{68} \mathrm{Ga}-\mathrm{DOTATATE}$ & Mid-left fibula & CECT & Concordant & Bone & NA \\
\hline
\end{tabular}

NA, not applicable.

fact that octreotide, a somatostatin receptor ligand, is largely ineffective in correcting the biochemical abnormalities in TIO $(43,44,45)$.

All the resected tumors $(n=22)$ were benign in nature. Sixteen of them (72.7\%) were found to have phosphaturic mesenchymal tumors (PMT) with the mixed connective tissue variant (PMTMCT) being most commonly seen in 15 patients, while one had an osteoblastoma-like variant. Three patients (13.6\%) had hemangiopericytomas while two had giant cell tumors (GCTs) and the other harbored an arteriovenous hemangioma. The present data is consistent with world literature showing a predominance of PMTMCT cases $(23,24)$. (c) 2019 The authors Published by Bioscientifica Ltd
Although surgery remains the mainstay of therapy, other treatment modalities have been tried with varying degrees of success. Image-guided ablation using different techniques (including percutaneousethanol ablation, radiofrequency ablation and cryoablation) offers a minimally invasive and safe treatment option for patients with inoperable TIO. However efficacy varies, and long-term effects are not known (46, 47, 48). Radiotherapy, as either an adjuvant or a primary treatment modality, remains a viable option for unresectable or incompletely resected tumors $(49,50)$. Deliberate total parathyroidectomy as a novel treatment approach has also been advocated in refractory cases (2).

This work is licensed under a Creative Commons Attribution-NonCommercial-NoDerivatives 4.0 
Cinacalcet and octreotide have been tried with variable success $(51,52)$. In addition, anti-FGF23 antibody, also known as KRN23 (Burosumab) is being evaluated for the treatment of TIO (53).

Postoperatively serum phosphorous normalized in 18 out of 22 patients over a period of 3 days to 2 months. Two patients $(9.1 \%)$ had a local recurrence within 6 months and had to be reoperated. A local recurrence rate of $<5 \%$ has been reported in world literature (54), mostly in patients harboring a malignant tumor or in whom the operating surgeon was not able to resect the tumor en bloc; the latter being the most likely reason in our two patients. In four patients (18.2\%), serum phosphorous never got normalized, and they were believed to have persistent disease. Disease persistence following surgical excision is well documented in literature (55). Repeat SSTR-based scintigraphy in these four patients revealed a new tracer-avid lesion in the right femur in one patient and the right foot of another patient. However, CEMRI was inconclusive. The other two patients had local residues but were unwilling for repeat surgery.

Postoperative FGF23 levels showed a statistically significant decline compared to preoperative values (Fig. 4). However, contrary to our expectations, FGF23 levels did not fall below the upper limit of the reference range of the assay $(0-150 \mathrm{RU} / \mathrm{mL})$ in four patients with unequivocal evidence of clinical and biochemical cure. This highlights the fact that the percentage decline in FGF23 after surgery, rather than the absolute value, correlates with disease cure. The mean percentage decline in FGF23 that was associated with clinical and biochemical cure was $81.1 \%$ (range $27.5 \%-99.2 \%$ ).

Serum phosphate in the surgically treated group was significantly higher at their last follow-up compared to the medically managed group $(P=0.006)$ (Fig. 5). However, even within the medically managed group, serum phosphate level at the last follow-up was significantly higher compared to baseline values $(P=0.001)$. Thus, phosphate and calcitriol supplementation in TIO patients, in whom the tumor cannot be localized, does improve biochemical milieu, whether this translates into improved quality of life is however debatable.

The principal strength of the study is the relatively large sample size. Prior case series from India were mostly single center experiences and had included no more than nine patients (15). On the contrary, this was a multicenter study involving 30 patients with cases being recruited from three tertiary care hospitals catering to the northern, western and southern parts of the nation. In addition, somatostatin receptor-based scintigraphy was used in most of the patients which is the best imaging modality as per published literature. Moreover, an attempt was made to correlate tumor characteristics with serum FGF23 levels (which might bear therapeutic implications) which, to the best of our knowledge, have never been reported earlier. The primary limitation of our study is the fact that not all of our patients underwent surgery; eight patients in whom either the tumor could not be anatomically localized or was unwilling for surgery were put on medical management. Hence, data on tumor histology was not available in these eight patients. Lastly, we measured serum FGF23 levels by C-terminal ELISA technique that measures both intact FGF23 and C-terminal fragments of FGF23. Traditionally it was believed that intact FGF23 was the only biologically active molecule mediating phosphaturia (56). Hence estimation of both intact and C-terminal fragments of FGF23 would theoretically overestimate the actual bioactivity of the circulating molecule.

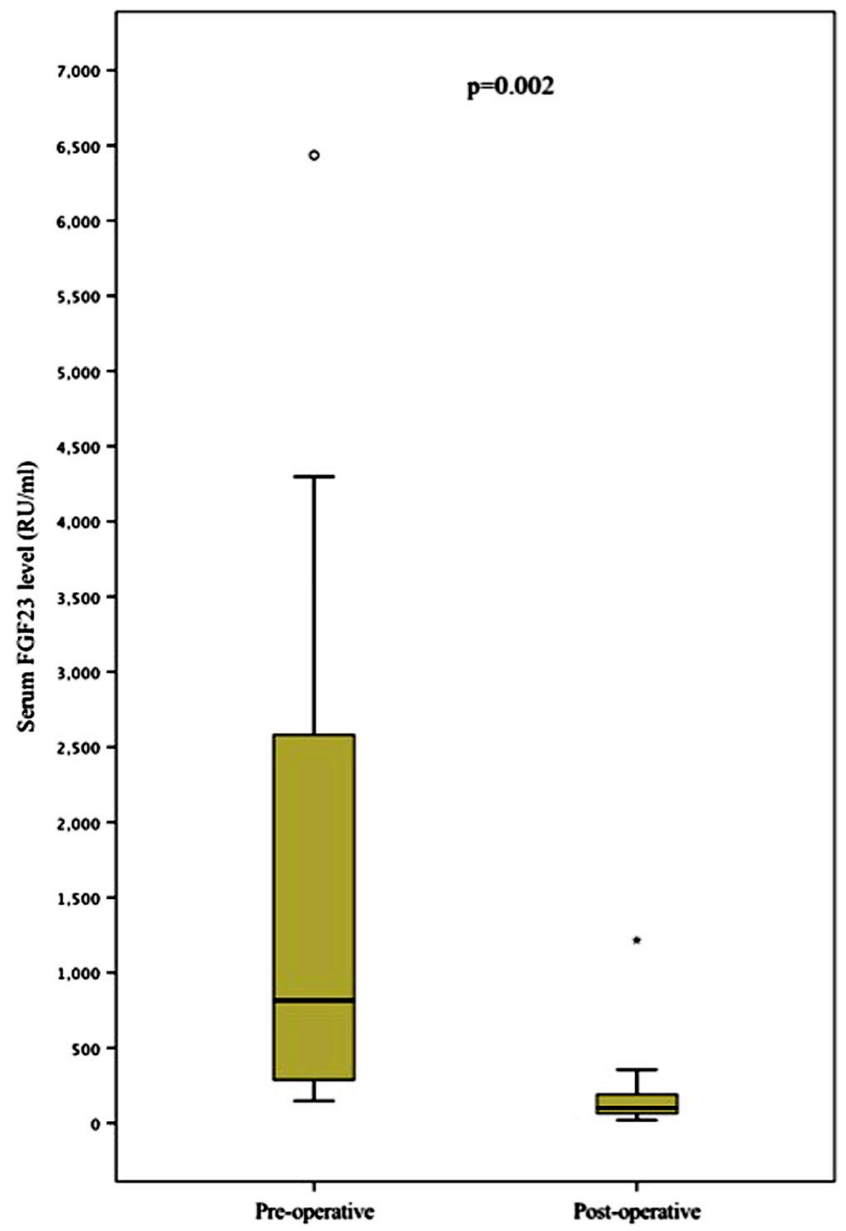

Figure 4

Box and whisker plot showing preoperative and postoperative serum FGF23 levels in 17 surgically treated TIO patients $(P=0.002)$. 


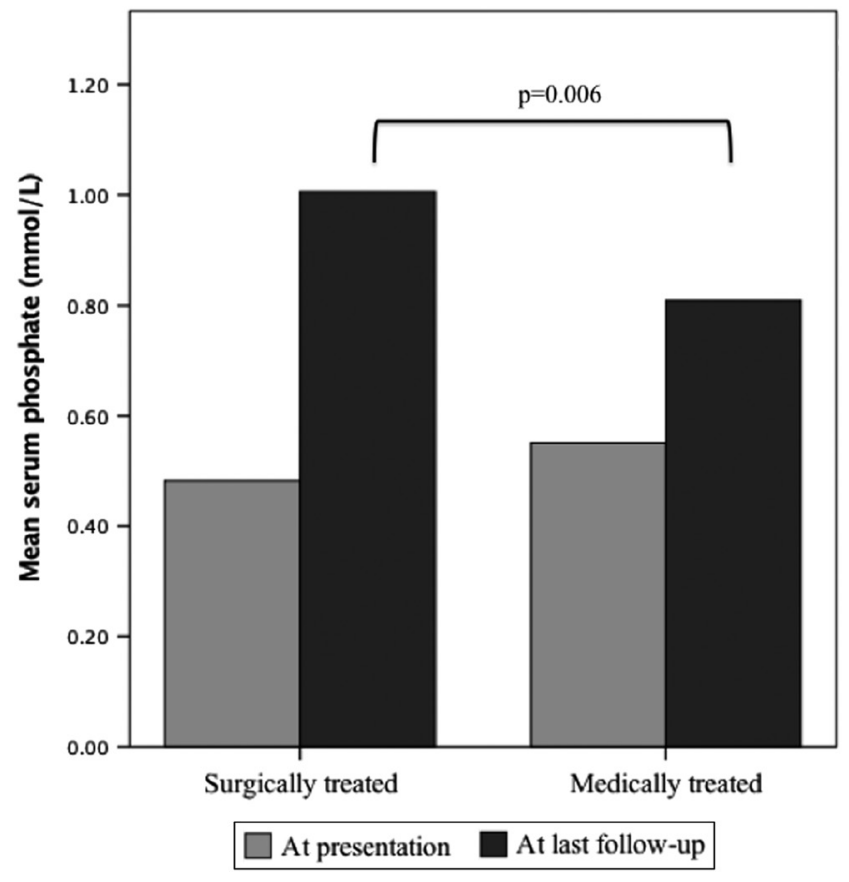

Figure 5

Bar diagram showing serum phosphate levels in surgically $(n=22)$ and medically $(n=8)$ treated TIO patients as measured at presentation $(P=0.217)$ and at their last follow-up $(P=0.006)$.

However, animal studies have shown that carboxyl terminal fragments of FGF23 are phosphaturic (57); the same might hold true for humans as well, and in fact, estimation of FGF23 by C-terminal ELISA might correlate better with bioactivity.

In conclusion, TIO should always be kept as a differential diagnosis while evaluating a patient for osteomalacia. Persistent hypophosphatemia despite normalization of vitamin D status in the absence of a similar family history strengthens the possibility of TIO. A thorough physical examination is always rewarding and might obviate the need for imaging. Serum FGF23 levels may be 'inappropriately normal' for the degree of hypophosphatemia. Somatostatin receptor-based scintigraphy should be used as the preferred imaging modality to localize the tumor. Surgical resection offers a definitive cure, however, recurrences do occur and longterm follow-up is necessary.

\section{Declaration of interest}

The authors declare that there is no conflict of interest that could be perceived as prejudicing the impartiality of the research reported.

\section{Funding}

This research did not receive any specific grant from any funding agency in the public, commercial or not-for-profit sector.

\section{Author contribution statement}

$\mathrm{R} P$ and $\mathrm{S} K \mathrm{~B}$ helped in the study design. The study was conducted by $\mathrm{R} P$ S K B and A B. Data collection was done by V D, A S, S K, M C, P C, D C S and VA. A S D provided scintigraphy data. U N S and D C provided histopathology data. Data analysis was done by R P and V D. Data interpretation was done by $S K B, R P$ and A B. R P, S K B, S K, A S D and M C helped in drafting the manuscript. S K B, S K, A S D and A S revised the manuscript content. $R P$, $S K B, A B, A S, M C, P C$ and S K. S K B approved the final version of the manuscript and take responsibility for the integrity of the data analysis.

\section{References}

1 Liu S \& Quarles LD. How fibroblast growth factor 23 works. Journal of the American Society of Nephrology 200718 1637-1647. (https://doi. org/10.1681/ASN.2007010068)

2 Bhadada SK, Palnitkar S, Qiu S, Parikh N, Talpos GB \& Rao SD. Deliberate total parathyroidectomy: A potentially novel therapy for tumor-induced hypophosphatemic osteomalacia. Journal of Clinical Endocrinology and Metabolism 201398 4273-4278. (https://doi. org/10.1210/jc.2013-2705)

3 Carpenter TO, Ellis BK, Insogna KL, Philbrick WM, Sterpka J \& Shimkets R. Fibroblast growth factor 7: an inhibitor of phosphate transport derived from oncogenic osteomalacia-causing tumors. Journal of Clinical Endocrinology and Metabolism 200590 1012-1020. (https://doi.org/10.1210/jc.2004-0357)

4 Rowe PS, Kumagai Y, Gutierrez G, Garrett IR, Blacher R, Rosen D, Cundy J, Navvab S, Chen D, Drezner MK, et al. MEPE has the properties of an osteoblastic phosphatonin and minhibin. Bone 2004 34 303-319. (https://doi.org/10.1016/j.bone.2003.10.005)

5 Schiavi SC \& Moe OW. Phosphatonins: a new class of phosphateregulating proteins. Current Opinion in Nephrology and Hypertension 200211 423-430. (https://doi.org/10.1097/00041552-20020700000009)

6 Shaikh A, Berndt T \& Kumar R. Regulation of phosphate homeostasis by the phosphatonins and other novel mediators. Pediatric Nephrology 200823 1203-1210. (https://doi.org/10.1007/s00467-0080751-z)

7 Berndt T, Craig TA, Bowe AE, Vassiliadis J, Reczek D, Finnegan R, Jan De Beur SM, Schiavi SC \& Kumar R. Secreted frizzled-related protein 4 is a potent tumor-derived phosphaturic agent. Journal of Clinical Investigation 2003112 785-794. (https://doi.org/10.1172/ JCI18563)

8 Alonso G \& Varsavsky M. Tumour-induced osteomalacia: an emergent paraneoplastic syndrome. Endocrinologia y Nutricion 2016 63 181-186. (https://doi.org/10.1016/j.endonu.2015.10.011)

9 Weidner N. Review and update: oncogenic osteomalaciarickets. Ultrastructural Pathology 199115 317-333. (https://doi. org/10.3109/01913129109016242)

10 Perwad F \& Portale AA. Vitamin D metabolism in the kidney: regulation by phosphorus and fibroblast growth factor 23 . Molecular and Cellular Endocrinology 2011347 17-24. (https://doi. org/10.1016/j.mce.2011.08.030)

11 Minisola S, Peacock M, Fukumoto S, Cipriani C, Pepe J, Tella SH \& Collins MT. Tumour-induced osteomalacia. Nature Reviews Disease Primers 20173 17044. (https://doi.org/10.1038/nrdp.2017.44)

12 Chong WH, Molinolo AA, Chen CC \& Collins MT. Tumor-induced osteomalacia. Endocrine-Related Cancer 201118 R53-R77. (https://doi. org/10.1530/ERC-11-0006)

13 Tarasova VD, Trepp-Carrasco AG, Thompson R, Recker RR, Chong WH, Collins MT \& Armas LAG. Successful treatment of tumor-induced osteomalacia due to an intracranial tumor by fractionated stereotactic radiotherapy. Journal of Clinical Endocrinology and Metabolism 201398 4267-4272. (https://doi.org/10.1210/ jc.2013-2528) 
14 Sun ZJ, Jin J, Qiu GX, Gao P \& Liu Y. Surgical treatment of tumorinduced osteomalacia: a retrospective review of 40 cases with extremity tumors. BMC Musculoskeletal Disorders 201516 43. (https:// doi.org/10.1186/s12891-015-0496-3)

15 Jagtap VS, Sarathi V, Lila AR, Malhotra G, Sankhe SS, Bandgar T, Menon P \& Shah NS. Tumor-induced osteomalacia: a single center experience. Endocrine Practice 201117 177-184. (https://doi. org/10.4158/EP10151.OR)

16 Sahoo J, Balachandran K, Kamalanathan S, Das AK, Patro DK, Halanaik D \& Badhe B. Tumor(s) induced osteomalacia-a curious case of double trouble. Journal of Clinical Endocrinology and Metabolism 201499 395-398. (https://doi.org/10.1210/jc.2013-3791)

17 Bhatt AA, Mathews SS, Kumari A \& Paul TV. Tumour-induced osteomalacia. Hong Kong Medical Journal 201420 350.e1-350.e2. (https://doi.org/10.12809/hkmj133981)

18 Ashish G, Mathew J, Thomas N, Kapoor N \& Elanthenral S. Phosphaturic mesenchymal tumour in the temporal bone - a rare presentation. Egyptian Journal of Ear, Nose, Throat and Allied Sciences 201415 149-153. (https://doi.org/10.1016/j.ejenta.2013.12.008)

19 Verma A, Tewari S \& Kannaujia A. Perioperative management of patients with severe hypophosphataemia secondary to oncogenic osteomalacia: our experience and review of literature. Indian Journal of Anaesthesia 201761 590-593. (https://doi.org/10.4103/ija. IJA_57_17)

20 Dutta D, Pandey RK, Gogoi R, Solanki N, Madan R, Mondal A, Dogra S \& Thapa P. Occult phosphaturic mesenchymal tumor of femur cortex causing oncogenic osteomalacia: diagnostic challenges and clinical outcomes. Endokrynologia Polska 201869 205-210. (https://doi.org/10.5603/EP.a2018.0016)

21 Annamalai AK, Sampathkumar K, Kane S, Shetty NS, Kulkarni S, Rangarajan V, Purandare N, Pai PS, Mahuvakar AD, Shanthi R, et al. Needle(s) in the haystack-synchronous multifocal tumor-induced osteomalacia. Journal of Clinical Endocrinology and Metabolism 2016 101 390-393. (https://doi.org/10.1210/jc.2015-3854)

22 Walton RJ \& Bijvoet OLM. Nomogram for derivation of renal threshold phosphate concentration. Lancet 19752 309-310. (https:// doi.org/10.1016/S0140-6736(75)92736-1)

$23 \mathrm{Yu}$ WJ, He JW, Fu WZ, Wang C \& Zhang ZL. Reports of 17 Chinese patients with tumor-induced osteomalacia. Journal of Bone and Mineral Metabolism 201735 298-307. (https://doi.org/10.1007/ s00774-016-0756-9)

24 Jiang Y, Xia WB, Xing XP, Silva BC, Li M, Wang O, Zhang HB, Li F, Jing HL, Zhong DR, et al. Tumor-induced osteomalacia: an important cause of adult-onset hypophosphatemic osteomalacia in China: report of 39 cases and review of the literature. Journal of Bone and Mineral Research 201227 1967-1975. (https://doi.org/10.1002/ jbmr.1642)

25 Dadoniene J, Miglinas M, Miltiniene D, Vajauskas D, Seinin D, Butenas P \& Kacergius T. Tumour-induced osteomalacia: a literature review and a case report. World Journal of Surgical Oncology $2016 \mathbf{1 4} 4$. (https://doi.org/10.1186/s12957-015-0763-7)

26 Ryan EA \& Reiss E. Oncogenous osteomalacia. Review of the world literature of 42 cases and report of two new cases. American Journal of Medicine 198477 501-512. (https://doi.org/10.1016/00029343(84)90112-8)

27 Florenzano P, Gafni RI \& Collins MT. Tumor-induced osteomalacia. Bone Reports 20177 90-97. (https://doi.org/10.1016/j. bonr.2017.09.002)

28 Folpe AL, Fanburg-Smith JC, Billings SD, Bisceglia M, Bertoni F, Cho JY, Econs MJ, Inwards CY, Jan De Beur SM, Mentzel T, et al. Most osteomalacia-associated mesenchymal tumors are a single histopathologic entity: an analysis of 32 cases and a comprehensive review of the literature. American Journal of Surgical Pathology 200428 1-30. (https://doi.org/10.1097/00000478-200401000-00001)

29 Qari H, Hamao-Sakamoto A, Fuselier C, Cheng YS, Kessler H \& Wright J. Phosphaturic mesenchymal tumor: 2 new oral cases and review of 53 cases in the head and neck. Head and Neck Pathology 201610 192-200. (https://doi.org/10.1007/s12105-015-0668-3)

30 Zuo QY, Wang H, Li W, Niu XH, Huang YH, Chen J, You YH, Liu BY, Cui AM \& Deng W. Treatment and outcomes of tumor-induced osteomalacia associated with phosphaturic mesenchymal tumors: retrospective review of 12 patients. BMC Musculoskeletal Disorders 201718 403. (https://doi.org/10.1186/s12891-017-1756-1)

31 Ritu G \& Gupta A. Vitamin D deficiency in India: prevalence, causalities and interventions. Nutrients 20146 729-775. (https://doi. org/10.3390/nu6020729)

32 Amblee A, Uy J, Senseng C \& Hart P. Tumor-induced osteomalacia with normal systemic fibroblast growth factor-23 level. Clinical Kidney Journal 20147 186-189. (https://doi.org/10.1093/ckj/sfu004)

33 Smith ER, McMahon LP \& Holt SG. Fibroblast growth factor 23 Annals of Clinical Biochemistry 201451 203-227. (https://doi. org/10.1177/0004563213510708)

34 Imel EA, Peacock M, Pitukcheewanont P, Heller HJ, Ward LM, Shulman D, Kassem M, Rackoff P, Zimering M, Dalkin A, et al. Sensitivity of fibroblast growth factor 23 measurements in tumorinduced osteomalacia. Journal of Clinical Endocrinology and Metabolism 200691 2055-2061. (https://doi.org/10.1210/jc.2005-2105)

35 Jonsson KB, Zahradnik R, Larsson T, White KE, Sugimoto T, Imanishi Y, Yamamoto T, Hampson G, Koshiyama H, Ljunggren O, et al. Fibroblast growth factor 23 in oncogenic osteomalacia and X-linked hypophosphatemia. New England Journal of Medicine 2003 348 1656-1663. (https://doi.org/10.1056/NEJMoa020881)

36 Burnett S-AM, Gunawardene SC, Bringhurst FR, Jüppner H, Lee H \& Finkelstein JS. Regulation of C-terminal and intact FGF 23 by dietary phosphate in men and women. Journal of Bone and Mineral Research 200621 1187-1196. (https://doi.org/10.1359/jbmr.060507)

37 Agrawal K, Bhadada S, Mittal BR, Shukla J, Sood A, Bhattacharya A \& Bhansali A. Comparison of 18F-FDG and 68Ga DOTATATE PET/ CT in localization of tumor causing oncogenic osteomalacia. Clinical Nuclear Medicine 201540 e6-e10. (https://doi.org/10.1097/ RLU.0000000000000460)

38 Jadhav S, Kasaliwal R, Lele V, Rangarajan V, Chandra P, Shah H, Malhotra G, Jagtap VS, Budyal S, Lila AR, et al. Functional imaging in primary tumour-induced osteomalacia: relative performance of FDG PET/CT vs somatostatin receptor-based functional scans: a series of nine patients. Clinical Endocrinology 201481 31-37. (https://doi. org/10.1111/cen.12426)

39 El-Maouche D, Sadowski SM, Papadakis GZ, Guthrie L, CottleDelisle C, Merkel R, Millo C, Chen CC, Kebebew E \& Collins MT. Ga-DOTATATE for tumor localization in tumor-induced osteomalacia. Journal of Clinical Endocrinology and Metabolism 2016 101 3575-3581. (https://doi.org/10.1210/jc.2016-2052)

40 Arai R, Onodera T, Terkawi MA, Mitsuhashi T, Kondo E \& Iwasaki N. A rare case of multiple phosphaturic mesenchymal tumors along a tendon sheath inducing osteomalacia. BMC Musculoskeletal Disorders 201718 79. (https://doi.org/10.1186/s12891-017-1446-z)

41 Higley M, Beckett B, Schmahmann S, Dacey E \& Foss E. Locally aggressive and multifocal phosphaturic mesenchymal tumors: two unusual cases of tumor-induced osteomalacia. Skeletal Radiology 2015 44 1825-1831. (https://doi.org/10.1007/s00256-015-2246-x)

42 Campana D, Ambrosini V, Pezzilli R, Fanti S, Labate AMM, Santini D, Ceccarelli C, Nori F, Franchi R, Corinaldesi R, et al. Standardized uptake values of 68Ga-DOTANOC PET: A promising prognostic tool in neuroendocrine tumors. Journal of Nuclear Medicine $2010 \mathbf{5 1}$ 353-359. (https://doi.org/10.2967/jnumed.109.066662)

43 Paglia F, Dionisi S \& Minisola S. Octreotide for tumor-induced osteomalacia. New England Journal of Medicine 2002346 1748-1749; author reply 1748. (https://doi.org/10.1056/ NEJM200205303462215)

44 Ovejero D, El-Maouche D, Brillante BA, Khosravi A, Gafni RI \& Collins MT. Octreotide is ineffective in treating tumor-induced osteomalacia: results of a short-term therapy: octreotide ineffective 
in treating tio. Journal of Bone and Mineral Research 201732 1667-1671. (https://doi.org/10.1002/jbmr.3162)

45 Mékinian A, Ladsous M, Balavoine AS, Carnaille B, Aubert S, Soudan B \& Wémeau JL. Curative surgical treatment after inefficient long-acting somatostatin analogues therapy of a tumor-induced osteomalacia. Presse Médicale 201140 309-313. (https://doi. org/10.1016/j.lpm.2010.10.011)

46 Jadhav S, Kasaliwal R, Shetty NS, Kulkarni S, Rathod K, Popat B, Kakade H, Bukan A, Khare S, Budyal S, et al. Radiofrequency ablation, an effective modality of treatment in tumor-induced osteomalacia: a case series of three patients. Journal of Clinical Endocrinology and Metabolism 201499 3049-3054. (https://doi.org/10.1210/jc.20134515)

47 Hesse E, Rosenthal H \& Bastian L. Radiofrequency ablation of a tumor causing oncogenic osteomalacia. New England Journal of Medicine 2007357 422-424. (https://doi.org/10.1056/NEJMc070347)

48 Tutton S, Olson E, King D \& Shaker JL. Successful treatment of tumor-induced osteomalacia with CT-guided percutaneous ethanol and cryoablation. Journal of Clinical Endocrinology and Metabolism 201297 3421-3425. (https://doi.org/10.1210/jc.2012-1719)

49 Caudell JJ, Ballo MT, Zagars GK, Lewis VO, Weber KL, Lin PP, Marco RA, El-Naggar AK, Benjamin RS \& Yasko AW. Radiotherapy in the management of giant cell tumor of bone. International Journal of Radiation Oncology, Biology, Physics 200357 158-165. (https://doi. org/10.1016/S0360-3016(03)00416-4)

50 Hautmann AH, Hautmann MG, Kölbl O, Herr W \& Fleck M. Tumorinduced osteomalacia: an up-to-date review. Current Rheumatology Reports 201517 512. (https://doi.org/10.1007/s11926-015-0512-5)

51 Geller JL, Khosravi A, Kelly MH, Riminucci M, Adams JS \& Collins MT. Cinacalcet in the management of tumor-induced osteomalacia. Journal of Bone and Mineral Research 200722 931-937. (https://doi.org/10.1359/jbmr.070304)

52 Seufert J, Ebert K, Müller J, Eulert J, Hendrich C, Werner E, Schütze N, Schulz G, Kenn W, Richtmann H, et al. Octreotide therapy for tumorinduced osteomalacia. New England Journal of Medicine 2001345 1883-1888. (https://doi.org/10.1056/NEJMoa010839)

53 Kinoshita Y \& Fukumoto S. Anti-FGF23 antibody therapy for patients with tumor-induced osteomalacia. Clinical Calcium 201424 1217-1222.

54 Yavropoulou MP, Gerothanasi N, Frydas A, Triantafyllou E, Poulios C, Hytiroglou P, Apostolou P, Papasotiriou I, Tournis S, Kesisoglou I, et al. Tumor-induced osteomalacia due to a recurrent mesenchymal tumor overexpressing several growth factor receptors. Endocrinology, Diabetes and Metabolism Case Reports 20152015 150025. (https://doi. org/10.1530/EDM-15-0025)

55 Chong WH, Andreopoulou P, Chen CC, Reynolds J, Guthrie L, Kelly M, Gafni RI, Bhattacharyya N, Boyce AM, El-Maouche D, et al. Tumor localization and biochemical response to cure in tumorinduced osteomalacia. Journal of Bone and Mineral Research 201328 1386-1398. (https://doi.org/10.1002/jbmr.1881)

56 Shimada T, Urakawa I, Isakova T, Yamazaki Y, Epstein M, WesselingPerry K, Wolf M, Salusky IB \& Jüppner H. Circulating fibroblast growth factor 23 in patients with end-stage renal disease treated by peritoneal dialysis is intact and biologically active. Journal of Clinical Endocrinology and Metabolism 201095 578-585. (https://doi. org/10.1210/jc.2009-1603)

57 Berndt TJ, Craig TA, McCormick DJ, Lanske B, Sitara D, Razzaque MS, Pragnell M, Bowe AE, O'Brien SP, Schiavi SC, et al. Biological activity of FGF 23 fragments. Pflugers Archiv 2007454 615-623. (https://doi. org/10.1007/s00424-007-0231-5)

Received in final form 24 January 2019

Accepted 28 January 2019

Accepted Preprint published online 6 February 2019 https://ec.bioscientifica.com https://doi.org/10.1530/EC-18-0552 (c) 2019 The authors Published by Bioscientifica Ltd
This work is licensed under a Creative Commons Attribution-NonCommercial-NoDerivatives 4.0 Internationab sicense.ifica . com at 04/26/2023 11:49:04AM 